International Journal of Current Advanced Research

ISSN: O: 2319-6475, ISSN: P: 2319 - 6505, Impact Factor: SJIF: 5.995

Available Online at www.journalijcar.org

Volume 6; Issue 5; May 2017; Page No. 3768-3775

DOI: http://dx.doi.org/10.24327/ijcar.2017.3775.0365

\title{
EFFECTS OF COOPERATIVE LEARNING STRATEGY ON SSS11 STUDENTS' COMPREHENSION OF READING PASSAGES IN EBONYI STATE OF NIGERIA
}

\author{
Chinyere Henrietta Maduabuchi and Blessing Ngozi Chukwu \\ Department of Arts and Social Science Education, Faculty of Education, \\ Ebonyi State University, Abakaliki Ebonyi State, Nigeria
}

\section{A R T T I C L E I N F O}

\section{Article History:}

Received $17^{\text {th }}$ February, 2017

Received in revised form $12^{\text {th }}$ March, 2017

Accepted $8^{\text {th }}$ April, 2017

Published online $28^{\text {th }}$ May, 2017

\section{Key words:}

English language; Reading comprehension Cooperative instructional strategy, Gender, and Achievement.

\begin{abstract}
A B S T R A C T
This study explored information on the effect of cooperative learning strategy on SS11 students' comprehension of reading passages in Ebonyi State of Nigeria. Non-equivalent control group design was adopted as the research design. The population of the study comprised nine thousand one hundred and eighty five (9185) students in all the 48 government co-educational secondary schools in the area of the study. A sample of one hundred and twenty (120) students from four intact classes was drawn from four coeducational schools. The English Language Achievement Test on Comprehension (ELATC) was the instrument used for data collection. Mean and standard deviation were used to answer the research questions while analysis of co-variance (ANCOVA) was used to test the null hypotheses. The results of the study revealed that cooperative instructional strategy has positive effect on students' comprehension of reading passages in English language due to its interactive pattern.; there is no significant difference on the mean achievement scores of male and female students taught comprehension passages with cooperative learning strategy and those taught with conventional method as both male and female students have the same achievement baseline. Based on these findings, the study recommended among other things that cooperative instructional strategy should be adopted in the teaching of reading comprehension passages in English language because its learner friendly attributes.
\end{abstract}

Copyright $₫ 2017$ Chinyere Henrietta Maduabuchi. This is an open access article distributed under the Creative Commons Attribution License, which permits unrestricted use, distribution, and reproduction in any medium, provided the original work is properly cited.

\section{INTRODUCTION}

Language is at the heart of human activities because almost every activity carried out by human beings employs the use of language, thus the enviable position it occupies in the curriculum. It is formally learnt in school with syllables drawn by experts and teachers trained to impact the language. One of the most encompassing definitions of language by Sapir as cited in Ngonebu (2008) states that language is a purely human and non-instinctive method of communicating ideas, emotions and desires by means of voluntarily produced symbols. Language in any society serves diverse functions, but the most important of these functions is the role of language as a medium of communication (Pelt, 2005), which is given such a central place as a result of the natural inclination of humans to pass information. This natural desire to share feelings, ideas and thoughts, in a highly multilingual

*Corresponding author: Chinyere Henrietta Maduabuchi Department of Arts and Social Science Education, Faculty of Education, Ebonyi State University, Abakaliki Ebonyi State, Nigeria nation like Nigeria creates a dire need for a language of inter ethnic and cross cultural communications; a language of unification and a language of national and inter ethnic communication.

As a result of the role of English as a language of international communication and the multi lingual nature of the Nigerian society, English language was voluntarily adopted in 1960 after independence as an official and interethnic communication in the country (Akabogu, 2006). English language since 1960 has come to serve various vital functions in the nation. Of all these functions however, its role as the language of education is paramount since education gives life and essence to all spheres of human endeavour (Obanya, 2004). This function is given greater vigor as a result of the position given to it by the National Policy on Education (2004), which makes the study of English language mandatory in secondary schools as it is used for assessing students' performance after primary school for the First School Leaving Certificate (FSLC), Junior Secondary School Certificate Examination (JSSCE), Senior Secondary School Certificate Examinations (SSCE), Joint Admission and Matriculation Board (JAMB) and other certificates as well as professional examinations. English language is a school 
subject and like every other school subjects, it requires formal instruction. Instruction in the English language involves instruction on the four basic language skills, listening, speaking, reading and writing. This is because acquiring a new language necessarily involves developing these four modalities in varying degrees and combinations (Tankersly, 2003).

Reading, which is one of the language skills, is the preoccupation of the study. Reading as a fundamental life skill, occupies a central position in the secondary school English language curriculum in Nigeria and reading lesson is the main vehicle for developing reading proficiency at the basic education level (Isiugo-Abanihe \& Maduabuchi, 2004). The reading process is never a passive process, but rather a dynamic process in which the reader is not only involved in information search, but he is engaged in information reformation, summarizing, editing, confirmation or rejection and criticism where necessary (Onukaogu, 2003).

Reading is the principal tool employed not only by students but by teachers in teaching and learning of any school subject. Nevertheless, a good number of students find it difficult to cope in reading lessons due to a number of factors of which one is the teaching strategy adopted by the teachers. For instance, a great number of failures have been recorded in students' performance in the English language. These failures were exemplified by an examination body called West African Examination Council (WAEC). According to the Chief Examiners Report (2014), out of the 1, 692, 435 candidates, comprising 929, 075 males and 763, 360 females who sat for the WAEC examinations in Nigeria, a total of 529, 425 candidates, representing 31.28 percent, obtained credits in five subjects and above, including English language. This analysis shows that $68.72 \%$ of the number of candidates who participated in the examination failed the English language. When compared to the 2012 and 2013 May/June WASSCE results, there is a marginal decline in the performance of candidates in English language.

This poor performance may be attributed to teachers' recurrent use of conventional method, which has been the mode of lesson presentation in Nigeria. Conventional teaching or traditional teaching refers to a teaching method involving instructors and the students interacting in a face-to-face manner in the classroom. These instructors initiate discussions in the classroom, and focus exclusively on knowing content in textbooks and notes. Students receive the information passively and reiterate the information memorized in the exams (McCarthy \& Anderson, 2012). This method of teaching has been observed many years to be the dominant method of teaching in most Nigerian schools. According to Offorma (2002), this method deals with rote learning and memorization as students are passive and not active. Invariably the method could lead to students' poor performance in school tasks. Omojuwa (2005) observes that most students, who fail to read, do so not because they are incapable of learning, but largely because of poor teaching strategies. Strategies adopted by teachers in teaching are crucial because teaching ought to be learner-focused and interactive. The International Reading Association (IRA) (2000) position paper on the methods debate as cited in Maduabuchi (2009:36) declares that: Learning to read and write is a complex multi-faced process that demands a wide variety of instructional approaches since no single method or combination of methods can successfully teach children to develop the skills and understanding they need to become a reader.

In similar vein, Lawal in Maduabuchi (2009: 36) opines that: The teaching of reading comprehension can no more be approached as an anything goes affair rather teachers of reading should deliberately adopt a well reasoned and professionally sound strategy that is founded on a thorough understanding of what the nature of the reading process is. Considering the enormity of hurdles students encounter in reading and comprehension of text types, one wonders how difficult words inherent in these passages are taught, who identifies difficult words-teachers, students or both? When difficult words are identified: before, during or after the comprehension passage has been read? What strategies are used? How and when are students tested, before or after the reading? All these are questions that should be answered to help students improve their ability in comprehension of reading passage

For learners to identify and understand lexical words in a passage of comprehension there is need for teachers of language to adopt good strategies that can promote students' interest in reading because it is a sin qua non for understanding a passage. Very little work seems to be done on how achievement in English language can be improved on by tapping from the social interest, needs and activities around the learner which engage and interest the learner; modifying the needs to have educational goals and relating it to reading proficiency. One of such area of focus which seems to have limited research attention in Nigeria is the use of cooperative learning strategies in developing students' ability in comprehension of reading passages in secondary schools.

Cooperative learning refers to students working in teams on an assignment or project under conditions in which certain criteria are satisfied, including that the team members be held individually accountable for the complete content of the assignment or project (Richard \& Rebecca, 2007). Cooperative learning is an approach to group work that minimizes the occurrence of the unpleasant situations and maximizes the learning and satisfaction that result from working in a high-performance team. This strategy creates a positive learning environment for students and allows students to have more opportunities for communication (Breck \& Jensen, 2007; Zhang, 2010). According to Daniels (2005), cooperative learning structures gives student a framework of support for their language learning experiences. From this framework, students will facilitate confidence in their language skills, so they will be comfortable in their learning environment and become more eager to speak out in class. She also pointed out that cooperative learning can increase language production, by integrating cooperative learning structures into foreign language lessons, the percentage of students active production of language can increase from $22 \%$ to $47 \%$ at any moment of speaking time. Additionally, cooperative learning can ensure that students talk meaningfully and in relation to the task being interdependent (Jollife, 2007). When students read comprehension passage in the English language, there is need for them to work together to complete objectives and make their ideas clear to others and extend themselves a bit to appreciate another's perspective on a problem. Cooperative learning utilizes the ideas of Vygosky, Piaget, and Kohlberg in that 
both individuals assert that the social setting are active dynamics in the learning process as students attempt to initiate real-life learning. By combining teamwork and individual accountability, student work towards acquiring both knowledge and social skills. It is a teaching strategy which allows students to work together in small groups with individuals of various talents, abilities and backgrounds to accomplish a common goal. Each individual team member is responsible for learning the material and also for helping the other members of the team learn. Students work until each group member successfully understands and completes the assignment thus creating an atmosphere of achievement (Guinevere, Rachel \& Rebecca, 2011). In the context of this study, cooperative learning strategy is a plan that may be adopted by English teachers to help students work together as team- mate particularly in the comprehension of reading passages in secondary schools.

Observation and experience have however, shown that teachers of English language in schools do not use this strategy to foster students' ability in reading passages. Cooperative learning strategy has over the past decades been proven to be learner friendly and fosters interaction of learners. The absence of this much needed meaningful interaction in the classroom therefore creates a gap between what is taught in the classroom, the experiences and activities the learners meet outside the classroom. It is critical that language teaching not only seeks to bridge this gap in order to make these two "word' closer, but of course also to harness the power of cooperation for instructional gain. It is for this reason that a research on the effect of cooperative learning strategy on students' comprehension of reading passages is not only imperative but also timely. Maduabuchi (2009:38) noted that. As the world is becoming globalized, it becomes imperative for students of language to work together to share experiences and develop their complex vocabularies. The vocabularies of a language are usually in constant flux because old items drop out, new terms come in and as the new ones replace and augment the old in like manner making the internal relation of the whole set to alter.

Many factors are likely to intervene on the effect of cooperative learning strategy on student's comprehension of reading passages, but in the context of this study, gender has been considered as an intervening variable. Gender refers to the amount of masculinity and feminity found in an individual (Bichi, 2002). Gender is a relative functions performed by male and female in the society. Gender could be defined as varied social and constructed roles, qualities, behaviours ascribed to men or women of different society (Bassow cited in Ogbu, 2008). Gender is a variable that plays important role in learning. The role an individual plays in society is distinguished by his or her gender. In other words, men are expected to behave in a certain way and to perform certain duties while women are expected to behave in certain ways and to perform certain duties. In the context of the study, gender is seen as a role that will be played by an individual in a group regards to male or female students. Gender comes into play in reading passage, when one remembers that personal orientation, abilities, and thinking styles play a crucial role in achievement. For instance, Sabiru (2014) found that there are differences that exist between male and female groups taught using collaboration learning strategies. Similarly, Uju and Fabian (2013) found that gender influences students in the production of Igbo standard phonology since female students did better than the male ones. However, Babajide (2010) found that there is no significant influence of gender in student's anxiety level in science subject. There are variations of findings on the influence of gender on students learning or reading ability.

From the foregoing, it is evident that comprehension of reading passage is an important aspect of English language. It is also a formal and complex skill that requires being taught and practiced by learners to gain proficiency. Maduabuchi (2009) opined that some lexical items pose difficulty to a second language learner depending on the way they are used. These lexical words according to her are idiom, words with several meaning, super-ordinates, transfer of meaning, and irony among others. Vocabulary item teaching as an aspect of comprehension passage should be given attention since it is the key towards effective comprehension of any given passage. Even though cooperative learning strategy has been tried in teaching science subjects, and other subjects, it appears that the strategy has not been employed by most language teachers possibly because, teachers have not been trained or made aware of the benefits of this method. This might be the reason students recorded massive failure in recent WAEC results. There is also need to test the efficiency of cooperative learning strategy as asserted by other researchers on students' comprehension of reading passages in this study. This makes it imperative for the researcher to investigate the effect of cooperative learning strategy on SSII students' comprehension of reading passages in Ebonyi State of Nigeria.

\section{Statement of the Problem}

English language teachers, parents and stakeholders in Language Education have been worried about the recurrent poor performance of students in SSCE English Language for quite some time now. Despite the important position of English language as the language of instruction in school system in Nigeria, it appears that many students do not have adequate opportunity to develop personal reading strategies that could enhance their comprehension ability due to the difficulties associated with the nature of the texts and teachers' constant use of conventional method of teaching reading, which has been the mode of lesson presentation in Nigerian school system. Teachers' use of the cooperative learning instructional strategies could have invariably helped in developing student's cognitive, affective and psychomotor abilities on comprehension. Therefore, the researcher wonders if secondary school English Language teachers use of the cooperative learning activities in teaching SS11 students' comprehension of reading passages would alleviate the problem of incomprehension that has marred the performance of students in Ebonyi State thus far hence, the problem of this study.

\section{Purpose of the Study}

The main purpose of this study is to determine the effect of cooperative learning strategy on SSII students' comprehension of reading passages in Ebonyi State.

\section{Specifically, the study sought to}

1. Determine the effect of cooperative learning strategy on SS11 students' comprehension of reading passages in Ebonyi State. 
2. Ascertain the difference in the mean achievement scores of students taught comprehension of reading passages using cooperative learning strategy and those taught using conventional method.

3. Ascertain the difference in the mean achievement scores of male and female students taught comprehension of reading passages with cooperative learning strategy those taught with conventional method.

\section{Research Questions}

\section{The following research questions guided the study}

1. What is the effect of cooperative learning strategy on SS11 students' comprehension of reading passages?

2. What is the difference in the mean achievement scores of students taught comprehension of reading passages using cooperative learning strategy and those taught using conventional method?

3. What is the difference in the mean achievement scores of male and female students taught comprehension of reading passages with cooperative learning strategy those taught with conventional method?

\section{Hypotheses}

Three (3) null hypotheses were developed and tested at 0.05 probability level of significance to guide the study.

$\mathbf{H O}_{1}$ : The effect of cooperative learning strategy on SS11 students' comprehension of reading passages is not statistically significant.

$\mathbf{H O}_{2}$ : There is no significant difference in the mean achievement scores of students taught comprehension of reading passages using cooperative learning strategy and those taught using conventional method.

$\mathbf{H 0}_{3}$ : There is no significant difference in the mean achievement scores of male and female students taught comprehension of reading passages with cooperative learning strategy.

\section{METHODOLOGY}

The study adopted a pretest posttest non-equivalent group control design. Abonyi, Okereke, Omebe \& Anugwo (2006) noted that non-equivalent control group or pretest post-test design is a design in which the researcher assumes that the treatment and control groups are not of initial equivalence and as such, there is no random assignment of subjects to treatment and control groups. In this design, there will be one experimental group formed by intact classes. In effect, the experimental group was exposed to cooperative learning strategy while non-experimental group was exposed to the conventional method.

\section{The design can be represented thus}

$$
\begin{array}{lll}
\mathrm{O}_{1} \quad \mathrm{X} \quad & \mathrm{O}_{2} \\
\mathrm{O}_{1} & \mathrm{O}_{2} \\
\text { Where } \mathrm{O}_{1}= & \text { Pre-test } \\
\mathrm{X}= & \text { Treatment of Experimental group } \\
\mathrm{O}_{2}= & \text { Posttest }
\end{array}
$$

The study was carried out in all the secondary schools in Onueke Education Zone. This zone is one of the three education zones in Ebonyi State. The Zone is made up of four local government areas namely: Ezza South, Ikwo, Ezza North and Ishielu. The area is bounded in the south by Afikpo and Ohaozara; in the north by Ohaukwu, Izzi and Abakaliki; in the west by Enugu and in the East by Cross-River respectively. The people of this area are predominant peasant farmers. The area is characterized by many languages spoken by the people. The predominant variant of the Igbo languages spoken by the people of this area are Ezza, Ikwo, Ezillo, Amuda, Ntezi and Agba dialects. These mother tongues could have influence on students' comprehension ability in English language. The physical environment of the area is characterized by plains, valley, hills and rivers which are conducive for using cooperative instructional learning strategies for teaching students' comprehension of reading passages. The area has also witnessed alarming increase in student's low performances in English language, which may be attributed to students' poor comprehension of reading passages (Ebonyi State Secondary Education Zone Onueke (EBSEZO, 2014). Thus, the choice of this area is to provide empirical indices on how cooperative learning strategy will help SS11 students' comprehension of reading passages which is vital for academic development of the area. The population of the study comprised nine thousand one hundred and eighty five $(9,185)$ students in all the 48 government coeducational secondary schools in Onueke Education Zone, Ebonyi State (SEB, 2015). Co-educational secondary schools were used because the study treated gender as a variable in the study. SSII students were used for the study because this is the class where the major concepts of English language are taught. The sample of the study was one hundred and twenty (120) students from four co-educational schools. Purposive sampling was used to select four (4) public schools from the zone on the basis of qualified teachers, functional resources and good environment. Four intact classes were used for the experiment.

The instrument for data collection was English Language Achievement Test on Comprehension (ELATC). The ELATC was drawn based on the table of specification. It covers four specific behaviours i.e. Knowledge, comprehension, Application and Analysis. The English Language Achievement Test on Comprehension (ELATC) was not face validated because it was adapted from the West African School Certificate Examination (WASCE) standard. The content validity of the instrument was ascertained using table of specification. The table of specification was to ensure that the items are selected based on the content areas and levels of behaviour covered. The internal consistency of the English Language Achievement Test on Comprehension (ELATC) was established using Kuder-Richardson formula 20. The researcher decided to use Kuder-Richardson formula 20 $\left(\mathrm{KR}_{20}\right)$ because the items were scored dichotomously (that is, right or wrong. The validated copy of the achievement test was administered to 30 students of English language in SS11 classes in two secondary schools in Abakaliki Education Zone, Ebonyi State. The students' responses analyzed yielded a reliability coefficient of 0.99 . This index is high and therefore, the instrument is reliable and was used for the actual study.

The Pre-ELATC was administered to the students. The experiment lasted for six weeks with one lesson period for each week, the normal school periods was used. The students were taught by the regular English language teachers while 
the researcher provided the rules, instructions and materials for the cooperative learning activity. The experimental group was taught using cooperative learning strategy while the control group was taught using conventional method of instruction. The data were analyzed based on the scores.

\section{Results}

Research question 1: What is the effect of cooperative learning strategy on SS11 students' comprehension of reading passages?

Table 1 Mean and standard deviation on the significant effect of cooperative learning strategy on SS11 students' comprehension of reading passages

\begin{tabular}{lccccc}
\hline \multirow{2}{*}{ Scores } & \multicolumn{2}{c}{$\begin{array}{c}\text { Experimental } \\
\text { Group }\end{array}$} & \multicolumn{2}{c}{$\begin{array}{c}\text { Control } \\
\text { Group(N) }\end{array}$} & \multicolumn{2}{c}{ (N0) } & \\
\cline { 2 - 6 } & Mean & SD & Mean & SD & Mean diff. \\
\cline { 2 - 6 } Pretest & 31.07 & 7.94 & 30.66 & 9.73 & 0.41 \\
posttest & 71.31 & 11.94 & 57.30 & 10.24 & 14.01 \\
Total & 51.19 & 9.94 & 43.98 & 9.99 & \\
\hline
\end{tabular}

Table 1 above shows that pretest mean and standard deviation achievement scores of experimental group are 31.07 and 7.94, while that of control group is 30.66 and 9.73 with mean difference of 0.41 . It could be observed that the two groups are in the same achievement baseline prior to instructional treatment. However, the posttest mean and standard scores of experimental group are 71.31 and 11.94, while that of control group are 57.30 and 10.24 with mean difference of 14.01 . This showed that experimental group achieved higher than that of the control group after instructional treatment. Therefore, cooperative learning strategy has positive effect on students' comprehension of reading passages in English language.

$\mathbf{H O}_{1}$ : The effect of cooperative learning strategy on SS11 students' comprehension of reading passages is not statistically significant.

Table 2 Analysis of Covariance on the effect of cooperative learning on students' performance in comprehension of reading passages

\begin{tabular}{cccccc}
\hline Source & $\begin{array}{c}\text { Type III Sum } \\
\text { of Squares }\end{array}$ & df & $\begin{array}{c}\text { Mean } \\
\text { Square }\end{array}$ & F & Sig. \\
\hline Corrected & $5991.859^{\mathrm{a}}$ & 2 & 2995.929 & 23.826 & 0 \\
Model & 42248.192 & 1 & 42248.192 & 335.985 & 0 \\
Intercept & 263.519 & 1 & 263.519 & 2.096 & 0.15 \\
Pretest & 5782.916 & 1 & 5782.916 & 45.99 & 0 \\
Method & 14712.066 & 117 & 125.744 & & \\
$\quad$ Error & 535141 & 120 & & & \\
Total & 20703.925 & 119 & & & \\
Corrected & Total & & & & \\
a. R Squared $=.289$ (Adjusted R Squared $=.277)$ & &
\end{tabular}

Table 2 above reveals that significance for two tailed tests under method (0.000) is less than the level of significance (0.05) that is $\mathrm{P}<0$. This means that the null hypothesis which states that effect of cooperative learning strategy on SS11 students' comprehension of reading passages is not statistically significant is rejected in favour of the alternative hypothesis. This means that the effect of cooperative learning strategy on SS11 students' comprehension of reading passages is statistically significant.
Research Question 2: What is the difference in the mean achievement scores of students taught comprehension of reading passages using cooperative learning strategy and those taught using conventional method?

Table 3 Mean and Standard Deviation achievement scores of students taught comprehension of reading passages using cooperative learning strategy and those taught using conventional methods.

\begin{tabular}{cccccc}
\hline \multirow{2}{*}{ Scores } & \multicolumn{2}{c}{$\begin{array}{c}\text { Experimental } \\
\text { Group(N=70) }\end{array}$} & \multicolumn{2}{c}{ Control Group(N=50) } \\
\cline { 2 - 6 } & Mean & SD & Mean & SD & $\begin{array}{c}\text { Mean } \\
\text { diff }\end{array}$ \\
\hline Pretest score & 3.23 & 0.32 & 3.09 & 0.35 & 0.14 \\
Posttest score & 3.31 & 0.29 & 2.81 & 0.29 & 0.50 \\
$\quad$ Total & 3.27 & 0.31 & 2.95 & 0.32 & \\
\hline
\end{tabular}

Table 3 above indicates that pre-interest mean and standard deviation achievement scores of experimental group are 3.23 and 0.32 , while that of control group is 3.09 and 0.35 with mean difference of 0.14 . It could be observed that the two groups are almost in the same achievement baseline prior to instructional treatment. However, the posttest mean and standard scores of experimental group are 3.31 and 0.29 , while that of control group are 2.81 and 0.29 with mean difference of 0.50 . This shows that experimental group achievement score became higher than that of the control group after instructional treatment.

$\mathbf{H O}_{2}$ : There is no significant difference in the mean achievement scores of students taught comprehension of reading passages using cooperative learning strategy and those taught using conventional method

Table 4 Analysis of covariance on the significant difference in the mean achievement scores of students taught comprehension of reading passages using cooperative learning strategy and those taught using conventional method

\begin{tabular}{|c|c|c|c|c|c|}
\hline Source & $\begin{array}{c}\text { Type III } \\
\text { Sum of } \\
\text { Squares }\end{array}$ & Df & Mean Square & $\mathbf{F}$ & Sig. \\
\hline $\begin{array}{c}\text { Corrected } \\
\text { Model }\end{array}$ & $7.926^{\mathrm{a}}$ & 4 & 1.981 & 24.024 & 0 \\
\hline Intercept & 8.363 & 1 & 8.363 & 101.406 & 0 \\
\hline Pretest & 0.34 & 1 & 0.34 & 4.124 & 0.045 \\
\hline Method & 5.445 & 1 & 5.445 & 66.025 & 0 \\
\hline method $*$ & 0.097 & 1 & 0.097 & 1.172 & 0.281 \\
\hline Error & 9.485 & 115 & 0.082 & & \\
\hline Total & 1169.543 & 120 & & & \\
\hline $\begin{array}{l}\text { Corrected } \\
\text { Total }\end{array}$ & 17.41 & 119 & & & \\
\hline
\end{tabular}

Table 4 above revealed that significance for two tailed test under methods $(0.000)$ is lower than the level of significance $(0.05)$ that is $\mathrm{P}>0$. This means that the null hypothesis which states that there is no significant difference in the mean achievement scores of students taught comprehension of reading passages using cooperative learning strategy and those taught using conventional method is rejected. This means that gender is not significant on students' interest in CRS and that role-play instructional strategy is gender friendly. There is significant difference in the mean achievement scores of students taught comprehension of reading passages using cooperative learning strategy and those taught using conventional method. 
Research Question 3: What is the difference in the mean achievement scores of male and female students taught comprehension of reading passages with cooperative learning strategy and those taught with conventional method?

Table 5 Mean and Standard Deviation achievement scores of male and female students taught comprehension of reading passages with cooperative learning strategy and those taught using conventional methods

\begin{tabular}{ccccccc} 
& \multicolumn{4}{c}{ Pretest score } & \multicolumn{2}{c}{ Posttest score } \\
\cline { 2 - 7 } Method & gender & $\mathbf{N}$ & Mean & SD & mean & SD \\
\hline \multirow{2}{*}{ experimental } & male & 31 & 31.58 & 10.45 & 73.68 & 11.61 \\
group & female & 39 & 30.67 & 5.26 & 69.44 & 12.01 \\
& Total & 70 & 31.07 & 7.94 & 71.31 & 11.94 \\
control group & male & 17 & 29.53 & 10.79 & 54.42 & 11.06 \\
& female & 33 & 31.24 & 9.26 & 58.79 & 9.63 \\
& Total & 50 & 30.66 & 9.73 & 57.3 & 10.24 \\
\hline
\end{tabular}

Table 5 shows that pretest mean and standard deviation scores of male students in experimental group are 31.58 and 10.45 and that of female in the same group are 30.67 and 5.26. For male in the control group pretest mean and standard deviation scores are 29.53 and 10.79 and that of female are 31.24 and 9.26. It could be seen that male and females students in the entire group exist almost in the same achievement baseline before instructional treatment. Also, the posttest mean and standard deviation scores showed that male students in experimental group had 73.68 and 11.61, whereas female students had 69.44 and 12.01; male students in the control group mean and standard deviation scores are 54.42 and 11.06, while that of female students are 58.79 and 9.63. It shows from the result above that after the instructional treatment, male students in experimental group achieved almost the same with that of female students, showing no gender biasness, same thing applies to control group.

$\mathbf{H O}_{3}$ : There is no significant difference in the mean achievement scores of male and female students taught comprehension of reading passages with cooperative learning strategy those taught with conventional method.

Table 6 Analysis of Covariance (ANCOVA) on the differences in the mean achievement scores of male and female students taught comprehension of reading passages with cooperative learning strategy those taught with conventional method

\begin{tabular}{|c|c|c|c|c|c|}
\hline Source & $\begin{array}{l}\text { Type III Sum } \\
\text { of Squares }\end{array}$ & df & $\begin{array}{r}\text { Mean } \\
\text { Square }\end{array}$ & $\mathbf{F}$ & Sig. \\
\hline $\begin{array}{c}\text { Corrected } \\
\text { Model }\end{array}$ & $6573.423^{\mathrm{a}}$ & 4 & 1643.356 & 13.374 & 0 \\
\hline Intercept & 42459.618 & 1 & 42459.618 & 345.554 & 0 \\
\hline Pretest & 319.495 & 1 & 319.495 & 2.6 & 0.11 \\
\hline Method & 6190.01 & 1 & 6190.01 & 50.377 & 0 \\
\hline Gender & 0.555 & 1 & 0.555 & 0.005 & 0.947 \\
\hline $\begin{array}{l}\text { method * } \\
\text { gender }\end{array}$ & 562.067 & 1 & 562.067 & 4.574 & 0.035 \\
\hline Error & 14130.502 & 115 & 122.874 & & \\
\hline Total & 535141 & 120 & & & \\
\hline $\begin{array}{c}\text { Corrected } \\
\text { Total }\end{array}$ & 20703.925 & 119 & & & \\
\hline a. R Squ & $\begin{array}{r}\mathrm{red}=.317(\mathrm{Adj} u \\
.294)\end{array}$ & , & Squared = & & \\
\hline
\end{tabular}

Table 6 above reveals that significance for two tailed test under gender $(0.947)$ is greater than the level of significance $(0.05)$ that is $\mathrm{P}>0$. This means that the null hypothesis which states that there is there is no significant difference in the mean achievement scores of male and female students taught comprehension of reading passages with cooperative learning strategy those taught with conventional method is accepted.
This means that gender is not significant on students' achievement in comprehension of reading passage and that comprehension of reading passage instructional strategy is gender friendly.

\section{Major Findings of the Study}

\section{The following findings were obtained from the data analysed in tables}

1. Cooperative instructional strategy has positive effect on comprehension of reading passages in English language.

2. There is significant difference in the mean achievement scores of students taught comprehension of reading passages using cooperative learning strategy and those taught using conventional method in favour of those taught with cooperative learning strategy.

3. Gender is not significant on students' achievement in comprehension of reading passage and that comprehension of reading passage instructional strategy is gender friendly.

\section{Discussion of Findings}

The study explored information of the effect of cooperative learning strategy on SS11 comprehension of reading passages in Onueke education Zone of Ebonyi State. The discussion of the findings was made based on the three research questions and three null hypotheses developed for the study.

The analysis of research question 1 revealed that cooperative learning strategy has positive effect on comprehension of reading passages in English language. This finding was further confirmed by the result of the null hypotheses which revealed that cooperative learning as a strategy has positive effect and a significant factor on students' achievement and comprehension of reading passages in English language. This also indicate that the strategy adopted in presenting reading passage to be learned has to do with students' achievement on comprehension of reading passage in English language. The higher achievement of students taught with cooperative learning strategy may be as a result of many factors. One of such factors according to Otagburuagu (2002) is making learning an active process, where the learner is totally immersed in learning activities which are of interest and appeal to him. During the lessons, many students felt the relaxations and creativeness with small discussion groups such that the drudgery associated with the typical classrooms was eliminated. Students therefore developed skills of identifying lexical and vocabulary words in comprehension passages. During the lesson also, the students learnt with the spirit of inquiry, competition and interest rather than simply memorization of comprehension passage. This finding is consistent with Usulor and Igba (2013) whose study found a significant effect of cooperative leaning strategy on students' achievement in school.

The analysis of research question 2 revealed that there is significant difference in the mean achievement scores of students taught comprehension of reading passages using cooperative learning strategy and those taught using conventional method. It is an indication that the grouping of students as instructional techniques had influence on the interest of students in reading passages. This finding is in agreement with Killen (2006) assertion that cooperative 
instructional strategy encourages all the group members to remain attentive and focus on the learning task which invariably led to students' high achievement in schools. This shows the extent to which students' comprehension in reading passage could be negatively or positively affected by the strategies adopted by the teachers.

The analysis of research question 3 revealed that gender is not significant on students' achievement in comprehension of reading passage because the strategy is gender focused. This means that teachers should improve the interest of students in comprehension of reading passages through cooperative learning strategy while equal opportunities should be given to both male and female students in English language learning activities. The finding also agreed with the view of Petal (1997) who found that gender of students is not a significant factor on students' interest and achievement in school work. To Petel, students' achievement on school subject is promoted by effective teaching methods. Thus cooperative learning strategy could be utilized by teachers of English language to promote students' achievement in secondary schools in Nigeria. It also buttressed the findings of Usulor and Igba (2013) and Ogbu (2008) on no significant difference in male and female achievement in Biology and social studies respectively using cooperative instructional strategy. Therefore, cooperative instructional strategy is an effective teaching strategy for bridging the gender gap differences in male and female achievement in comprehension of reading passages in secondary schools in Nigeria.

\section{CONCLUSION}

The result of this study showed that cooperative instructional strategy has a significant effect on students' academic achievement and comprehension of reading passage and that cooperative instructional strategy has the efficacy of removing the gender biasness in instruction. It is therefore, concluded that putting into practice the recommendations of this study based on the findings would not only lead to students' comprehension of reading passage but bridge the gap between the male and female participation in learning and achievement in English language and other subjects in school system in Nigeria. More so, the implementation of cooperative instructional strategy in teaching students comprehension of reading is highly strategic in the $21^{\text {st }}$ century where learning/teaching are made more dynamic so as to meet changing tides.

\section{References}

Abonyi, S.O., Okereke, S. C., Omebe, C. A., \& Anugwo, M. (2006). Foundation of educational research and statistics. Enugu: Fred-Ogah Publisher.

Akabuogu, J. (2006). The relevance of ICTs in the teaching and learning of English as the second language in Nigeria secondary schools. In D. Eze, \& N. Onyegebu (eds.), information and communication technology in the service of education. International Journal of Education, 1(1), 225-247.

Akabuogu, J.U., \& Obiezu, M.N. (2013). Effect of manual games on junior secondary school students' achievement and motivation in English language vocabulary in Enugu state Education Zone. International Journal of Education Research, University of Nigeria Nsukka, 1(12), 1-7.
Bichi, S.S. (2002). Effect of problem-solving strategy and enriched curriculum on secondary school students' achievement in evolution concept. $A \quad P h D$ Dissertation presented to the department of education A.B.U. Zaria, Nigeria.

Breck, R., \& Jensen, J. (2007). Cooperative learning responsibility, ambiguity, controversy and support in motivating students. Insight: A Journal of Scholarly Teaching, 2(1), 57-63.

Daniels, K.M. (2005). Cooperative learning structures for English foreign language classroom. Journal of Tourism Studies, 4(1). 143-149. retrieved form www.rdarc.itakura.toyo.ac.jp/webday.ashino/public/ki you/rtvo4/rt-v4-143.pdf.

Ebonyi State Secondary Education Zone Report (2014). School performance analysis. Ebonyi Central (Onueke) Zone: SEB publication.

Federal Republic of Nigeria (2004). $4^{\text {th }}$ edition National Policy on Education. Lagos: NERDC Press

International Reading Association (2000). Making a difference means making a different: Honouring children' right to excellent reading instruction. Delaware: IRA Publication.

Isiugo-Abanife, I.M., \& Maduabuchi, C. H. (2004). Instructional scaffolding support strategy, cooperative learning and students' comprehension of texts. Nigerian Journal of Applied Psychology, 8 (2), 256273.

Jolliffe, W. (2007). Cooperative learning in the classroom: Putting it into practice. London: Paul Champion.

Killin, R. (2006). Effective teaching strategies (4 $\left.{ }^{\text {th }} \mathrm{ed}\right)$. Victoria: Thomas learning Nelson.

Maduabuchi, C.H. (2009). Strategies of teaching difficult words of reading comprehension lesson. Ebonyi State University Journal of Arts and Social Science Education, 1 (1), 35-42.

McCarthy, J. P., \& Anderson, L. (2012). Active learning techniques versus traditional teaching styles: Two experiments from history and political science," Innovative Higher Education, 24(4), 279-294.

Ngonebu, 1. (2008). Fundamentals of second language learning. Nsukka: Afro-Obis Publication.

Obanya, P. (2002). Curriculum overloard in the language education programme for basic education. In $\mathrm{L}$. Adebayo, I. Isungo-Abanike, and I.N. Ohi, (eds) perspectives on Applied linguistics in language and literature. Ibadan: Stirling-Horden Publishers Ltd.

Offorma, G.C. (2002). Curriculum implementation and institution. Onitsha: Uni-world Educational Publishers Ltd.

Offorma, G.C. (2005). Curriculum across language. Onitsha: Uni-world Educational Publishers Ltd.

Ogbu, C. (2008). Effect of cooperative and product learning strategies on senior secondary school students' achievement in essay writing. Unpublished Ph.D Thesis, Ebonyi State University, Abakaliki.

Omojuwa, J. (2005). Laying a strong foundation for high level reading achievements: Problems and prospects. Journal of Applied Literacy and Reading, 1(2), 7-16

Onukaogu, C.E. (2003). Towards the understanding of reading. In C.E. Onukaogu, A.E. Arua \& O.B. Jegede (eds.). Teaching reading in Nigeria: A guidebook to 
theory and practice. Newark, DE. International Reading Association.

Otagburuagu, E. (2002). The English language in Nigeria: Some historical landmarks. In E. Otagburuagu and P. Anyanwu, (eds) concepts and issues in language studies (pp 73-94). Owerri: Cel publishers.

Pelt, N.V. (2005). Heart to heart: The art of communication. Spain: Sam Fernando De Henares.

Punch Newspaper (2014). Chief examiner report of May/June WASSCE. 1.16 million People fail English language. Tuesday, August 12, page 8

Richard, M.F., \& Rebecca, B. (2007). Cooperative learning: Model for analytic science. American Chemical Society, pp. 34-53.

Sabiru, D.Y. (2014). Effect cooperative learning on chemistry students' achievement and anxiety level in balancing chemical equations in secondary schools in Katsina Metropolis, Nigeria. Journal of Education and Vocational Research, 5 (2), 43-48
Tankerly, K. (2003). Threats of reading: strategies for literacy development. Virginia: Association for Supervision and Curriculum Development.

Uju, C.U., \& Fabian, U.U. (2013). Influence of gender on senior secondary school students in the production of standard Igbo phonology. International Journal of Arts and Technology Education, 9 (1), 142-156

Usulor, B.E., \& Igba, D.I. (2013). Using cooperative learning instructional strategy in solving the problem of gender stereotyping on junior secondary school students' achievement Social studies. International Journal of Research in Arts and Social Sciences, 6 (1), 354-361.

WAEC (2013) students' performance in reading comprehension passage in WAEC examination: Public Affairs Department of WAEC, Lagos. Retrieved from http://www.casestudiesjournal.com

Zhang, Y. (2010). Cooperative language learning and foreign language learning and teaching. Journal of Language Teaching Research, 1 (1), 81-8

\section{How to cite this article:}

Chinyere Henrietta Maduabuchi and Blessing Ngozi Chukwu (2017) 'Effects Of Cooperative Learning Strategy On Sss11 Students' Comprehension Of Reading Passages In Ebonyi State Of Nigeria', International Journal of Current Advanced Research, 06(05), pp. 3768-3775. DOI: http://dx.doi.org/10.24327/ijcar.2017.3775.0365 